\title{
Modern Greek Language
}

National Cancer Institute

\section{Source}

National Cancer Institute. Modern Greek Language. NCI Thesaurus. Code C153909.

Refers to the dialects and varieties of the Greek language spoken in the modern era. 